\title{
ORNAMENTS OF LAPO BATAKIN KUALA TANJUNG, BATUBARA REGENCY A SEMIOTICSINTERPRETATION
}

\author{
Oleh: \\ Elisa Betty Manullang ${ }^{1)}$ \\ Windy Lizasadela ${ }^{2)}$ \\ Universitas Negeri Medan ${ }^{1,2)}$ \\ E-mail: \\ elisamanullang@gmail.com ${ }^{1)}$ \\ windylizasadela@gmail.com ${ }^{2}$
}

\begin{abstract}
This article aims at clarifying the semiotic meaning in Lapo Batak ornaments in Kuala Tanjung, Batubara Regency. The data of this study were taken from the interpretation from Batak Toba people who live in Kuala Tanjung, Batubara Regency is located in North Sumatera Indonesia in interpreting their cultural symbols. In clarifying the data, the writing was conducted by using qualitative method. The result showed the semiotic meaning and how the cultural values were realized in Lapo Batak ornaments. The data were analyzed by using Roland Barthes' order of significationtheory; denotation, connotation, and myth to emphasize the interaction between the sign with the personal cultural experience of the viewers, and the interaction between convention in the sign with the conventions experienced and expected by viewers. The writer found that the interpretations of the personal cultural experience from the viewers were still far from the Batak Toba convention (myth) in interpreting the ornaments.
\end{abstract}

Keywords: Connotation, Denotation, Lapo Batak ornaments, Myth, Semiotic

\begin{abstract}
ABSTRAK
Artikel ini bertujuan untuk menjelaskan makna semiotic pada ornament warung Batak yang berada di Kuala Tanjung, kabupaten Batu Bara. Data pada artikel ini diambil dari interpretasi dari orang suku Batak Toba yang tinggal di Kuala Tanjung, Kabupaten Batu Bara. Kabupaten Batu Bara berlokasi di Sumatera Utara, Indonesia, dalam menginterpretasikan symbol budaya mereka. Dalam menjelaskan data tersebut, penulis melakukannya dengan menggunakan metode Qualitative. Hasilnya menunjukkan bahwa makna semiotic serta bagaimana nilai budaya itu ditampilkan pada ornament yang ada di warung batak. Data-data tersebut dianalisa dengan menerapkan teori Roland Barthes terhadap denotasi, konotasi, serta mitos untuk menekankan interaksi antara tanda-tanda pengalaman secara pribadi terhadap pandangannya dan interaksi antara konvensi tanda dengan konvensi pengalaman dan harapan pandangan. Penulis menemukan bahwa interpretasi pengalaman nilai budaya secara pribadi dari pandangan masih jauh dari konvensi (Mitos) dalam menginterpretasikan ornament-ornamen tersebut
\end{abstract}

\section{Kata Kunci :Konotasi, Denotasi, Ornament WarungBatak, Mitos, Semiotik}

\section{CHAPTER I: INTRODUCTION}

Language is a way to communicate one another. According to Wijana (2016: 195) from the language can be known from the circle or social class where the person is from or from the language, maybe it can also be known from the region or what ethnicity the person came from. But, language is not only about words. According to DeMichele, language is symbolic in more ways than can be summarized in a sentence or paragraph, 
but generally it talks about how symbols can stand for something else, how they can be used to communicate, and how they can be imbued with meaning. For example, of symbolic language: the word cat is symbolic of the idea of a cat, a dollar is a symbol of $\$ 1$ of economic value, the word yes or a nod is a symbol of confirmation, a grimace is a symbol of disapproval, and a smiley face emoji is a symbol of happiness.

(http://factmyth.com/factoids/language-isa-system-of-communication-that-uses-

symbolism/, June 1, 2020) According to Sebeok, words in general are symbolic signs. But any signifier - object, sound, figure, etc. - can be symbolic. A cross figure can stand for the concept 'Christianity' ; a V-sign made with the index and middle fingers can stand symbolically for the concept 'victory' ; white is a colour that can be symbolic of 'cleanliness', 'purity', or 'innocence', but dark of 'uncleanness, 'impurity', or 'corruption'; and the list could go on and on. These symbols are all established by social convention. (Sebeok, 2011: 11)

When we say "language is symbolic" we are not talking about "what wesay" (what symbols we use), but "what we mean" (what the symbols we use mean; what we are trying to communicate). Language is symbolic in that the symbols weuse have a deeper "symbolic and semantic" meaning beyond their literal meaning. The study of this can be called semiology (or semiotic, as it is known better in America).

According to Saussure, semiology (from the Greek Semeion "sign") studies the life of sign within societies. This is general approach to the study of sign.In every cultural life, or even of culture as a sort of language. He proposed dualistic notion of the sign, relating the signifier as the form of the word or phraseuttered, to the signified as the mental concept. And it's important to note thataccording to Saussure, the sign is completely arbitrary, there was no necessary connection between the sign and its meaning Roland Barthes proposed another term to understand the sign by histheory's order of signification where the sign has three stages in meaning; denotation, connotation, and myth. To conclude, Chandler in his book, Semiotics, The Basics; wrote "Tosemioticians, a defining feature of signs is that they are treated by their users as 'standing for' or representing other things." (Chandler, 2007: 60)In Batak Toba culture, there are so many symbols with its hidden meaning especially ornaments in Lapo Batak. Lapo, in Kamus Bahasa Batak Tobaby Op. Faustin Panjaitan (2010: 130), means warung, kedai (food stall). Lapo Batakis not only about a restaurant that serves food, but it is also a place where Batak people gather. They will also get closer to their family members of the same clan.

For Bataknese, it is required the involvement of each family from each clan todiscuss anything about the culture; marriage, births, and also funeral ceremonies. In Lapo Batak, there are a lot of symbols with differential meanings, suchas; gorga, ulos, and a picture of goldenfish (ornaments).The writer is interested in analysing the ornaments in Lapo Batak in Kuala Tanjung, Batubara Regency since the ornaments are not just for decorations as advertising, but there arealso some interesting meanings behind 
it, and the writer would be able to do itssocial context on how Batak people see their cultural symbols.Based on the background of the study, the writer formulates the problems of this article as follows:

1. What semiotic meaning are in Lapo Batak ornaments culture?

2. How are the cultural values of Lapo Batak ornaments in Medan?

Based on the research question above, the writer has several objectives ofthe article as follow:

1. To identify the semiotic interpretation in Lapo Batakornaments culture.

2. To elaborate the cultural values of Lapo Batak ornaments in Kuala Tanjung, Batubara Regency.

To avoid an overlapping and misleading discussion, this article was only focused on Batak Toba ornaments in 2 Lapo Batak in kuala Tanjung Regency, namely; RM. Padao Holso, and RM. Khas Batak Silindung with 8 ornaments in total. The study used Barthes's order of signification theory to analyse the data to get the semiotic meaning behind the ornaments. The analysis of this research is expected to be able to give significancefor the reader, the resultsof the research are expected to give explanation on how signs portrayed on ornaments in Lapo Batak in Kuala Tanjung Batubara Regency. It is also expected to give explanation about how Barthes' order of signification theory can be implied in interpreting signs in Lapo Batak ornaments in Kuala Tanjung Batubara Regency. For practical significance, the results of the research are expected topromote Batak culture and their characteristics not only for Indonesian but also forinternational. It is also expected to give knowledge about Batak ornaments to peopleespecially Batak people so the cultural heritage will not be vanished.

\section{CHAPTER II :THEORETICAL FRAMEWORK}

Semiotic or semiology, as it better known in Europe) originate from the Greek semeion, which mean sign. Semiotics is a general study about the signs as anessential part of cultural life and communication. According to semiotics, we canonly know culture and reality by means of the sign, through the process of signification. According to Danesi (2004, 3-4) on his book, Messages, Signs, and Meaning, he says that semiotics is the science that attempts to answer the following question: What does $\mathrm{X}$ mean? The $\mathrm{X}$ can be anything from a single word or gesture, to an entire musical composition or film. The "magnitude" of X may vary, but thebasic nature of the inquiry does not. If we represent the meaning (or meanings) thatX encodes with the letter $\mathrm{Y}$, then the central task of semiotic analysis can bereduced, essentially, to determining the nature of the relation $\mathrm{X}=\mathrm{Y}$. Let's take, as a first case-in-point, the meaning of red. In this case, our $\mathrm{X}$ constitutes an Englishcolor term. As it turns out, there is hardly just one answer to the question of what itmeans. At a basic level, it refers of course to a primary color located at the lowerend of the visible spectrum. However, that very color can have a host of othermeanings. Here are few of them:

- If it appears as a traffic signal, it means "stop" to anyone facing the signalat an intersection 
- If it is the armband color worn by someone at a political rally, then thewearer is perceived to be an individual who espouses a particular land ofpolitical ideology, often labelled as "left-wing" or "radical."

- If it is the colour of the flag used by someone at a construction site, thenit is a signal of "danger."

- If it is used in an expression such as "turning red," then it is a figure ofspeech that allows people to refer to emotional states without namingthem precisely.

In sum, red is an example of a sign. It is something, $\mathrm{X}$ (a color), thatstands for something else, Y (a traffic signal, a political ideology and so on).

\section{Some Theories of Semiotic}

There are a lot of semiotician in the world. But, the writer only focuseson the theories from three famous experts of semiotic.

\subsection{Ferdinand de Saussure}

Saussure's definition of the sign laid down the course that semioticinquiry was to take during the first half of the twentieth century. He defined it as aform made up (1) of something physical - sounds, letters, gestures, etc. - which hetermed the signifier; and (2) of the image or concept to which the signifier referswhich he called the signified. He then called the relation that holds between the twosignifications. Saussure considered the connection between the signifier and thesignified an arbitrary one that human beings and/ or societies have established at will.

For Saussure, both the signifier (the 'sound pattern') and the signified

(the concept) were purely 'psychological'.
The relationship between the signifier and the signified is referred to as 'signification', and this is represented in the Saussurean diagram by the arrows. Thehorizontal broken line marking the two elements of the sign is referred to as 'the

bar'. (as cited in Chandler, 2007, 14-15)If we take a linguistic example, the word 'open' (when it is invested withmeaning by someone who encounters it on a shop doorway) is a sign consisting of:

- a signifier: the word 'open';

- a signified concept: that the shop is open for business.

\subsection{Charles Sander Peirce}

At around the same time as Saussure was formulating his model of thesign and of 'semiology' (and laying the foundations of structuralist methodology), was also in progress as the pragmatist philosopher and logician Charles SandersPeirce formulated his own model of the sign, of 'semeiotic [sic]' and of thetaxonomies of signs.

Signified

Signifier

In contrast to Saussure's model of the sign in the form of a 'self-containeddyad', Peirce offered a triadic (three-part) model consisting of:

1. The representamen:

The form which the sign takes (not necessarily material, though usuallyinterpreted as such) - called by some theorists the 'sign vehicle'.

2. An interpretant:

It is not an interpreter but rather the sense made of the sign.

3. An object:

It is something beyond the sign to which it refers (a referent).

In Peirce's own words: 
A sign . . . [in the form of a representamen] is something which stands tosomebody for something in some respect or capacity. It addresses somebody, that is, creates in the mind of that person an equivalent sign, or perhaps a moredeveloped sign. That sign which it creates I call the interpretant of the first sign.

The sign stands for something, its object. It stands for that object, not in all respects,but in reference to a sort of idea, which I have sometimes called the ground of therepresentamen. (as cited in Danesi, 2007: 29).

To qualify as a sign, all three elements are essential. The sign is a unityof what is represented (the object), how it is represented (the representamen) and how it is interpreted (the interpretant).

The sign is more than just a sign vehicle. The term'sign' is often used loosely, so that this distinction is not always preserved. In theSaussurean framework, some references to 'the sign' should be to the signifier, andsimilarly, Peirce himself frequently mentions 'the sign' when, strictly speaking, heis referring to the representamen. It is easy to be found guilty of such a slippage

perhaps because we are so used to 'looking beyond' the form which the signhappens to take. However, to reiterate: the signifier or representamen is the form inwhich the sign appears (such as the spoken or written form of a word) whereas the

sign is the whole meaningful ensemble.The interaction between the representamen, the object and theinterpretant is referred to by Peirce as 'semiosis'.
The three elements that make up a sign function like a label on an opaquebox that contains an object. At first the mere fact that there is a box with a label onit suggests that it contains something, and then when we read the label we discoverwhat that something is. The process of semiosis, or decoding the sign, is as follows. The first thing that is noticed (the representamen) is the box and label; this promptsthe realization that something is inside the box (the object). This realization, as wellas the knowledge of what the box contains, is provided by the interpretant.

\section{Representamen Object}

'Reading the label' is actually just a metaphor for the process of decoding the sign.The important point to be aware of here is that the object of a sign is always hidden.We cannot actually open the box and inspect it directly. The reason for this issimple: if the object could be known directly, there would be no need of a sign torepresent it. We only know about the object from noticing the label and the box andthen 'reading the label' and forming a mental picture of the object in our mind.Therefore the hidden object of a sign is only brought to realization through theinteraction of the representamen, the object and the interpretant.The representamen is similar in meaning to Saussure's signifier while theinterpretant is roughly analogous to the signified. However, the interpretant has aquality unlike that of the signified: it is itself a sign in the mind of the interpreter.

Peirce noted that 'a sign . . . addresses somebody, that is, creates in the mind of thatperson an equivalent sign, or perhaps a more developed sign.'Peirce also 
identified 66 different types of signs, of which three are usedcommonly in all kinds of semiotic work today. They are called icons, indexes, and

symbols. (as cited in Danesi, 2004: 27)

\section{The Cosmology of Batak Toba}

According to Irawan and Lukuhay (2012: 3 ), there are two kinds of ideasabout the origin or cosmology of Batak tribe. First idea was told by Ypes, said thatBatak tribe was originally from Northern Asia, then moved to Formosa inPhilippines, and continued to move toward South Sulawesi, who then finallybecame Toraja, Bugis, and Makassar. After that, they moved to Sumatera throughLampung, South Sumatera, downed the west coast to Barus and still moved on toBukit Barisan Mountain in PusukBuhit, which is one of the areas near Lake Toba.The second idea said that Batak tribe was originated from India who thenspread around Southeast Asia in Muang Thai Burma, then moved to GentingKeraland in North Malaysia and sailed from Malay peninsula toward the east coast ofSumatera, then moved to Batubara coast and downed the river toward Lake Toba.

In fact, there was another route they took, that was from Malacca to the west coastof Aceh and moving forward to Singkil, Barus, or Sibolga and finally stayed inPusukBuhit.

\section{Cultural Awareness}

According to Collins Dictionary (collinsdictionary.com), someone'scultural awareness is their understanding of the differences between themselves andpeople from other countries or other backgrounds, especially differences in attitudesand values.Cultural Awareness is the foundation of communication and it involvesthe ability of standing back from ourselves and becoming aware of our culturalvalues, beliefs and perceptions.

Batak Toba Cultural Awareness in Attitudes

The attitudes of Batak Toba people is based on their three philosophies;Dalihan $\mathrm{Na}$ Tolu, Suhi Ni Ampang Na Opat, and Umpama, Umpasa, andPhilosophy. Those philosophies are the guidelines in behave manners customary inthe interactions to kinship groups.

\section{Dalihan Na Tolu}

"Dalihan" means a stove made of a stone, while "DalihanNatolu" is acooking stove placed on three stones. The three stones are made as a place for thecooking stove on it. The dalihan that is made must be the same size and placed ormust be planted on the ground, and the spacing and height should be balanced witheach other, so that the dalihan will not tilted. Usually, cooking with dalihannatolu

is sometimes uneven because the support stones are not aligned. To be aligned,other objects are used to prop up. In everyday language, most Toba Batak peopleadd the objects to block. They are called sihalsihal.Dalihan $\mathrm{Na}$ Tolueffected the presence of kinship social crisis on the thirdgeneration after Si Raja Batak, as impact of marriage with the same clan betweenTuan Sariburaja with his sister (iboto) named BoruPareme. Both are the son anddaughter of TateaBulan as the second generation. As the consequence of whatSariburajawas doing, he ran into the forest while BoruPareme also expelled fromSianjurMulaMula Village. Then the classification began to members of the societywith the categories of the SombaMarhula-hula, Manat Mar dongan 
Tubu (friend ofone clan), and Elek Marboru.

(http://www.gobatak.com/filsafah-orangbatak-tobadalam-

dalihan-natolu/, June 1, 2020)

\section{SombaMarhulahula}

Hula-hula in the Batak tradition are the male family of the wife ormother, commonly called tunggane by the husband and tulang by the child. In theBatak tradition which is paternalistic, the one who proposes is the male, so if womenoften come to the house of men who are not their relatives, it is called bagottumandangisige (violating the rules). There is an aphorism in Batak language, "Nasosombamarhula-hula, siraraon ma gadongna". Gadong for Batak people isconsidered one of the staple foods as a substitute for rice, especially for breakfastor lunch. Siraraon is a condition of sweet potato (gadong) that tastes bland as if itis rotten and runny. The statement implies that those who do not respect the hula hula will have a difficulty making a living.

\section{Manat Mardongan Tubu}

The picture of Dongan Tubu is the figure of siblings. Psychologically indaily life, the relationship between siblings is very close. But one time therelationship will be tenuous, it can even cause a fight. "Angka naso manat mardongan tubu, natajom ma adopanna". The phrase is reminiscent, people with

one clan must have experienced disputes, disputes that often ended with physica lfighting. In Batak custom, there is a term panombol or parhata which defines therepresentative suhut (host) in the custom that is applied. That is why, to plan a habit (friend's party or death), namardongantubu (siblings) always talk about it first. Itis useful for avoiding mistakes in implementing customs. In general, panombol orparhata are taken one level below and / or one level above each clan.

\section{ElekMarboru}

Boru is a group of people from sister, and the clan of her husband or thefamily of a woman from a clan. In everyday life we often hear the term elek marboru which means to love one another so that they can get blessings. The term Boru in Batak culture does not look at status, position, and wealth.

\section{Suhi Ni Ampang Na Opat}

In the Batak culture, there is a very thick piece of equipment seen in itsrole, namely ampang orbasket. It is thick because in terms of its use, the tool isvery useful to be a place or container. But it is also has another meaning as a symbol that focuses on the meaning of the four angles in the ampang or basket.The values contained in Suhi Ni Ampang Na Opat / four angles of a basketare defined as four angles of the same size and the same function and must alsoexist at the same time. The values in Suhi Ni Ampang Na Opat show the noble values in the human's heart; holong (love), dame (peace), lasniroha (joy), and harapan (hope)

(https://www.tobatabo.com/416+apa-artisuhi-ni-ampang-na-opatdalamadat-batak.htm, June 1 2020).

In Batak custom event, the symbolic of Suhi Ni Ampang Na Opat is akinship in a Batak traditional party. One of the representatives of the four family elements must take a part, if not, the naopatsuhi will not functioned as it should.But, that rarely happens because the family-relatives must 
fulfill it in order to makea customary event happens. The four family-relatives are(https://www.hitabatak.com/arti-suhini-ampang-na-opat/, June 1, 2020);

1. SuhutSihabolonan: the family who will carry out the custom event.

2. Namarhahamaranggi: the siblings of those who will carry out the custom event.

3. Saboltok: the siblings from the level of the father or grandfather who will carry out the custom event.

4. Boru: the clans who take the women who will carry out the custom of Boru.

\section{Umpama, Umpasa, and Philosophy}

Umpasa is a kind of rhyme (first sentence explains the last sentence), but actually it is tantamount to a prayer of blessing to be blessed by God. All those whohave rhymes must confess in their hearts that God is the One who gives blessings.

Umpama is a sentence of equality that is almost similar to the philosophy ofold men. If you say a proverb, don't say the sentence (contents) of a poem, and vice versa, if you rhyme, don't say a proverb.The philosophy of parents is like the equation but most of the experiences of old - time parents can be advice especially to young people. (http://sianporsea.

blogspot.com/2011/09/pengertian-umpasaumpama-dan-falsafah.html,

June 1, 2020)

Batak Toba Cultural Awareness in Values

As stated by BasyralHamidyHarahap and Hotman M. Siahaan, the valueof Batak culture includes all aspects of Batak people's lives. In this context, thereare at least nine main Batak cultural values, namely: (1) Kinship, (2) Religion, (3)Hagabeon, (4) Hasangapon,
Hamoraon, (6) Hamajuon,

Patikdohotuhum,

(8) Shelter and (9) Conflict. (as cited in Ritonga 2012: 250-251)

\section{Kinship}

Kinship, which includes tribal premordial relations, affection on the basisof blood relations, harmony of the elements of Dalihan Na Tolu (Hula-hula,DonganTubu, Boru), PisangRaut (AnakBoru from AnakBoru), Hatobangon

(Intellectual) and all related relations kinship due to marriage, clan solidarity andothers.

\section{Religious}

Religious, includes religious life, both traditional religions and later religions that regulate its relationship with the Creator and its relationship with humans and their environment.

\section{Hagabeon}

Batak people hope to have many descendants and long life. There is afamous Batak traditional expression conveyed at a wedding ceremony. It is a hopeexpression that the newlyweds will be given 17 sons and 16 daughters. Human

\section{CHAPTER III: DATA AND DATA ANALYSIS}

\section{A. Data}

As the writer explained in the previous chapter, this study dealt withsemiotic interpretation on ornaments in LapoBatak in Kuala Tanjung by Bataknese wholive in Kuala Tnjung Regency. The data of this study were ornaments in LapoBatak There were gorga, ulos, and a picture of golden fish which found in LapoBatak inKuala Tanjung Regency. 


\section{B. Data Analysis}

In this section, the data and data analysis of the ornaments in LapoBatakin Kuala Tanjung were given to solve the research problems, which were: what semioticmeanings are in LapoBatak ornaments culture and how are the semiotic meaning srealized in Batak cultural values. The data were analysed by using Barthes' semiotic theory; denotation, connotation, and myth to identify the semiotic meanings of Lapo Batak ornaments culture. In this data analysis, the amount of the ornaments (data)

1. Roland Barthes Semiotic Analysis for Gorga Boraspati

Denotation meaning in Gorga Boraspati was a lizard-shaped with twobranches. Lizards were usually located above the house and are located on the wallsof the traditional house on the right and left side of the front house and beside Gorga Adop Adop. (Rayking, 2013: 39)

In connotation meaning based on Bataknese people interpretations, Gorga Boraspati was interpreted as a symbol of eternity life since lizards was neversleep, a symbol of easy adaptation since lizards are in every human's houses, asymbol of strict people with hard tone since lizards could make a loud sound, asymbol of Lapo owner's hope to have a lot of customers come to the lapo since theappearance of lizard's voice might be a sign to tell that there was someone'scoming, a symbol of respect for Muslim to warn Muslim that the lapo is a non-halalplace that serves forbidden dishes since there was a history which led lizards asforbidden animals, a symbol of loyalty since a lizard can stick to a wall withoutfalling, a symbol of survivor since lizards can sever their tails to fool its enemy, asymbol of wealth according to viewer's belief, a symbol of worth since therespondent saw the ornament as a gecko which was expensive and has benefits, a

symbol of peace since lizard likes to live indoors, and a symbol of honesty sincelizard can look forward and backward might be a sign that Bataknese was not ahypocritica.These interpretations fit to Harahap \& Siahaan's theory of Batak Tobacultural values; Hagabeon (hope to have many descendants and long life), Hamajuon (encouraging Batak people to migrate), Hamoraon (wealth), and shelter.In myth meaning, GorgaBoraspati or lizard often gave certain signsthrough behavior and sound that could help humans avoid danger. Boraspati wasrarely seen or appears. When it was often seen, it indicated that the plants werefertile which led to wealth.

2. Roland Barthes Semiotic Analysis for Gorga Simeoleol

Gorga Simeoleol in denotation meaning was a form of tendrils that areintertwined with the impression of waddle that produces beauty and is located oneach side of the traditional Batak Toba house board. Simeoleol means to waddle. (Rayking, 2013: 69) In connotation meaning, Gorga Simeoleol was interpreted by Batakneseas a symbol of seriousness since every round of the ornament had something to tellthat if the rotation was wrong, it could bring death, a symbol of wealth since theornament looks like a living plant form which usually symbolized wealth, a symbolof courage since there is a red color on the ornament, a symbol of harmony basedon the respondent's beliefs, a symbol of shelter since those colors of the 
ornamentwere made from the blood of the Batak warriors during the war, a symbol of valuesand regularities of life based on respondent's beliefs, a symbol of justice since thetwo ornaments coincided and were facing each other, a symbol of survivor since itwas a picture of sea waves that reminding Batak people even though there weremany waves of obstacles, Batak people were able to survive, a symbol of kinshipsince each colors of the ornament were unbroken and mutually interlocking, asymbol of danger repellent since it was respondent's beliefs, and a symbol ofunity since it was illustrated with opposite ends but remained a unified whole so asto provide a mutually binding rhythm of motion. These interpretations fit to Harahap \& Siahaan's theory of Batak Tobacultural values; hamoraon (wealth), shelter, patik dohot uhum (the value of truth inthe world of law), kinship, and Batak Toba cultural attitudes; dalihannatolu (whichshould have 3 stones with the same size so that the dalihan will not tilted /harmonizing).In myth meaning, Gorga Simeoleol was as an attitude and behavior aboutlove for Toba Batak art, such as dancing (manortor, martumba). Gorga Simeoleolsymbolized joy.

3. Roland Barthes Semiotic Analysis for Gorga Simataniari

Gorga Simataniari in denotation meaning was in the shape of the sun.The sun in daily life was usually above the sky which gave blazing (heat) to humans.It was placed in the middle of the Toba Batak traditional house and next to it wasGong. (Rayking, 2013: 48)In connotation meaning, GorgaSimataniari based on the interpretationsof Bataknese was a symbol of hope to make the lives of Batak people brighter, asymbol of light for the life of the Batak people, a symbol of wealth since theornament was like an eye and its position was placed in front of the lapo whichsignifying it was a vision to look for fortune, a symbol of power with the light givenby the sun, a symbol of seriousness since it was not just any gorga must be unitedwith GorgaIponIpon, Iran Iran, Simataniari, and UluPaung or if not it would bringdeath, a symbol of adaptation since it was a picture of eight points of compass whichencouraged Batak people to scatter in all directions, a symbol of leader since it hada black dot and was placed in the middle which meant there was only one leader ina home, a symbol of wholeness since it was a picture of a drum that has a circlewhich symbolizes a relationship between people must be intact, a symbol ofcourage since it was respondent's beliefs, and a symbol of unity since it was apicture of a motorcycle wheel motif that it was used to coat motorcycle tires andunited with tires.These interpretations fit to Harahap\&Siahaan's theory of Batak Tobacultural values; hamoraon (wealth), hasangapon (power), and hamajuon(encouraging Batak people to migrate).In myth meaning, GorgaSimataniari means a source of life force anddeterminant of the way of life in the world, so that everyone can work to fulfil theirdaily lives, and will alleviate all problems if they want to work diligently.

4. Roland Barthes Semiotic Analysis for GorgaIponIpon

GorgaIponIpon in denotation meaning looks like teeth. Humans withoutteeth cannot eat. Likewise, without GorgaIponipon, the Toba Batak traditional 
house would not be beautiful. It was located on the edge of the Toba Batak traditional house, with its wide between two to three centimeters on the edge of theboard. (Rayking, 2013: 44)

In connotation meaning, GorgaIponIpon based on the interpretations ofBataknese was a symbol of obedience to God since the ornament was placed underGorga Tunggal Pangaduan (which the viewer meant GorgaUluPaung), a symbol of openness since the ornament has several holes on each side that make the windcan penetrate the ornament, a symbol of togetherness since every picture in thisgorga was the same picture and concided, a symbol of beauty since this ornamenthad some triangles that arranged neatly and produced beauty, a symbol of kinshipsince this ornament had straight lines and coincided, a symbol of courage (redcolor), purity (white color), and sadness (black color), a symbol of strength sincethe ornament was made of strong woods, and a symbol of authority since it was astick that symbolized authority according to the respondent.These interpretations fit to Harahap\&Siahaan's theory of Batak Tobacultural values; religious, kinship, and, hasangapon (power/authority).In myth meaning, GorgaIponIpon means harmony, meaning everyfamily that occupies the house is a harmonious family and if there are problems inthe family it will be resolved peacefully and deliberately. As the nature and behavior of the Toba Batak community in over cominga problem, the Toba Batak community has a philosophy of Dalihan Na Tolu; sombamarhula-hula, manat mardongan tubu, and elek marboru. So, the problem is solvedby deliberation.
5. Roland Barthes Semiotic Analysis for Gorga Iran Iran

Gorga Iran Iran in denotation meaning was a kind of human face makeupmaterial to make it look more beautiful. The gorga was usually located on the leftand right sides of the Batak Toba traditional house. (Rayking, 2013: 60)

In connotation meaning, Gorga Iran Iran was interpreted by Bataknese asa symbol of light since the shape of the gorga looks like a star; a symbol of advicesince the ornament looked like a Batak letter which was usually contained of someadvices; a symbol of protector since it was like a safety for another gorga becauseit was placed under another gorga; a symbol of harmony since the ornament hastwo same carvings and is placed side by side which signified Batak people liked tolive side by side; a symbol of beauty since the ornament has curved lines whichproduced beauty; a symbol of wealth since the ornament is a symbol of theKingdom of Bataknese which represented prosperity; a symbol of openness sincethe ornament is a fence that can be opened and closed; a symbol of shelter since itwas a picture of scorpion which its poison was released to fight the enemy; a symbolof simplicity since the placement of the ornament in the front lapo represented afundamental life, and at the bottom of the roof represented a low profile; a symbolof beauty since the ornament resembles flower petals; and a symbol of wisdom andaffection since the ornament was a combination of Gorga Boraspati and Gorga Adop Adop. These interpretations fit to Harahap \& Siahaan's theory of Batak Tobacultural values; kinship, and hamoraon (wealth).In myth meaning, Gorga Iran Iran means a symbol 
of beauty. So, everyperson who occupies the house is a person who is beautiful from the face andbehavior in their daily lives.

6. Roland Barthes Semiotic Analysis for Gorga Ulu Paung

Gorga Ulu Paung in denotation meaning was a giant decoration in theform of half human and half animal, often found in the form of a buffalo hornedhuman head. It was at the top end of the Batak Toba traditional house. (Rayking,2013: 57) Connotation meaning of GorgaUluPaung was interpreted by Batakneseas a symbol of shelter since it was a buffalo head that has sharp horns and nosewhich was considered as an icon to scare bad people, a symbol of power since theornament was placed upon any other gorga in one carving which represented theposition of a king, a symbol of strength since the ornament looks like a giant facethat has a big and strong body posture, a symbol of hope to have a son since theornament looks like a shape of human's head wearing a crown which usually pinnedon male, and a symbol of braveness since the ornament looks like a sword's hiltwas usually used by warriors who were brave and tough.These interpretations fit to Harahap \& Siahaan's theory of Batak Toba cultural values; shelter, hasangapon (power), and the cultural attitudes theory; suhiniampangnaopat which its values showed love, peace, joy, and hope.In myth meaning, Gorga Ulu Palung symbolized power. So, everyone who occupied the house was a person who was alert and quick to face all the trialsand distress. In addition, this gorga was also a sign to fight begu (ghosts) comingfrom outside the village. So, if Gorga Ulu Paung was on a house, then the people who occupied the house would get along in a family and produced a harmoniousrelationship.

7. Roland Barthes Semiotic Analysis for Goldfish picture In denotation meaning, the ornament is a picture of goldfish. Goldfish isa Batak typical food that was served in Batak customIn connotation meaning, it was interpreted by Bataknese as a symbol ofwealth since the oils in the goldfish that entered the stomach were believed to be afortune; a symbol of blessing and prayer, a symbol of harmony because just likegoldfishes who like to go hand in hand, the Batak people also want their culture,customs, and religion to go hand in hand; a symbol of freshness since goldfisheslive in the fresh water; a symbol of gratitude since the ornament was believed to bean icon to show gratitude as something desired has been achieved; a symbol ofpersistence in pursuing their goals like goldfish that swim against the flow; and asymbol of kinship since goldfish always go together and support one another.These interpretations fit to Harahap\&Siahaan's theory of Batak Toba cultural values; kinship, and hamoraon (wealth).In myth meaning, dengke (goldfish) is a symbol of fertility / manyoffspring, a symbol of blessing from the bride's parents, good livelihood and asymbol of affection from the bride's parents.

8. Roland Barthes Semiotic Analysis for UlosSadum

Ulossadum in denotation meaning was an ulos that will be given tonamboru (sister of the father) of the bride and groom that will be worn by hula-hula(sister or brother of the mother) during the Batak customary marriage. (Agustina,2016: 3)In connotation meaning, Ulos Sadum was 
interpreted by Bataknese as asymbol of marriage since it was an icon to give blessing at a wedding; a symbol ofblessing; a symbol of advice; a symbol of shelter since ulos is believed to protectBatak people from evils; a symbol of prayer; a symbol of hope since this ulos wasgiven to people who were expecting something to happen; a symbol of simplicity

since the ulos has its cultural meaning that Bataknese should live in simplicity andcare for others; a symbol of wealth since ulos was intended that Batak people whoreceived ulos would get a prosperous life; a symbol of warmth since Batak peopleused to live in highlands which has cold temperatures and used ulos to warm them; a symbol of kinship since ulos could be used at the same time to more than oneperson which meant to bind to each other in a family relationship; a symbol ofpower since the ornament was UlosBintangMaratur(Maratur Star) which wasexpensive as seen from its name "star" that usually associated with people who havehigh positions such as generals; a symbol of strength since it was believed givestrength or power to women.These interpretations fit to Harahap\&Siahaan's theory of Batak Tobacultural values; shelter, religious, hamoraon (wealth), kinship, hasangapon

(power), and the cultural attitudes theory; suhiniampangnaopat which its values

showed love, peace, joy, and hope.UlosSadum in myth meaning was a proof of love from a hula-hula totheir children.

\section{Research Findings}

Ornament is functioned to decorate or beautify a place. but, suchornament might have a hidden meaning. The meaning is caused from certaincommunity or cultural perspectives or an ideology of a group. For an individual interpretation, people interpret a sign using their own knowledge and experience.Based on Barthes's order of signification theory, LapoBatak ornaments gavecertain information to the respondents related to the ornament's characteristic,their own knowledge, beliefs, experiences, and Batak cultural ceremonies. Toconclude, there were a lot of respondents who did not know the real meaning of theLapoBatak ornaments.

\section{Discussion}

Based on Saussure, the linguistic sign was defined as two side entity. Oneside of the sign was what he called the signifier, a material aspect of a sign.Inseparably from the signifier in any sign, engendered by the signifier was whatSaussure called the signified as the mental concept.More specific to Saussure's model of the sign in the form of a 'self-containeddyad', Peirce offered a triadic (three-part) model consisting ofrepresentamen, interpretant, and object. The representamen was similar in meaningto Saussure's signifier while the interpretant was roughly analogous to the signified.However, the interpretant has a quality unlike that of the signified: it was itself asign in the mind of the interpreter.Meanwhile, Barthes' order of signification theory continued the thoughtof Saussure by emphasizing the interaction between the sign with the personal andcultural experience of its users, and the interaction between convention in the signand the conventions experienced and expected by its users.In a research about "GorgaSopoGodangPadaMasyarakatBatak 
TobaKajianSemiotik" which was conducted by Rayking (2013) there was also a similarmethod in doing a semiotic analysis of gorga. In his research, the method was depthinterview with the people who were in Simanindo Village while this study used thesame method but with Bataknese who lived in Medan. The researcher used hisresults to conclude the data by using Roland Barthes' semiotic theory; denotation, connotation, and myth.

\section{Conclusion}

Having identified and analysed all the data, the findings of this research

could be concluded as follows:

1. The semiotic meaning in the LapoBatak ornaments are realized usingBarthes' order of signification theory which are denotation, connotation, and myth.LapoBatak ornaments gave certain informations to the respondents related to theornament's characteristic, their own knowledge, beliefs, experiences, and Batakcultural ceremonies. But, most respondents did not know the real meaning of theornaments.

2. The cultural values which realized in the semiotic meaning of LapoBatakornaments were; kinship, religious, hagabeon, hasangapon, hamoraon, hamajuon,patikdohotuhum, and shelter.

\section{Suggestion}

Considering the conclusions that had been drawn above, severalsuggestions regarding the topic of this study were served and listed as follows:

1. To increase the appreciation of Batak ornament in its development eitheras an appreciator nor a creator. It is expected to be able to develop andapply a semiotic approach in understanding the existence of the BatakToba ornaments
2. The findings of this study were expected to give knowledge of thesemiotic meaning of LapoBatak ornaments to Bataknese since it is theircultural ornaments. The findings also could be used as a comparison tothe other researches.

\section{REFERENCES}

Agustina, C. (2016).

MaknadanFungsiUlosdalamAdatMasyarak atBatak Tobadi

DesaTalangMandiKecamatan Mandau

KabupatenBengkalis. JOM

FISIP Vol. 3 No. 1, 1-15.

Aprilia,

V.

(2016).MaknaSimbolikKomunikasiBudaya

dalamUpacaraAdat

PerkawinanMasyarakatBatak Toba di

PekanBaru.Jom FISIP, 1-15.

Chandler, D. (2004). Semiotics The Basics.

New York: Psychology Press.

Chandler, D. (2007). Semiotics The Basics.

New York: Routledge.

Creswell, J. W. (2009). Research Design;

Qualitative, Quantitative, and Mixed

Methods Approaches. California: Sage Publication.

Danesi, M. (2004). Messages, Signs, and Meanings: A Basic Textbook in Semiotics and Communication Theory. Toronto: Canadian Scholars' Press Inc.

DeMichele, T. (2015). Language is a System of Communication that Uses Symbolism.Fact / Myth.

Gobatak. (2011, October 17). gobatak.com. Retrieved from gobatak.com:

http://www.gobatak.com/filsafah-orang-

batak-toba-dalam-dalihan-natolu/

Hitabatak. (2017, September 21). ArtiSuhi

$\mathrm{Ni}$ Ampang $\mathrm{Na}$ Opat. Retrieved from 
Hita

Hutahaean, W. (2016).Semiotics Analysis of RumahAdatBolonBatak Toba. The

Episteme Journal of Linguistics and Literature Vol. 2 No. 3, 1-30.

49

Hutauruk, I., \&Zulkifli. (2012).

AnalisisSemiotikaOrnamenBatak Toba Pada

GerejaKatolikKristus Raja SemestaAlam Stasi Sarudik-SibolgaTapanuli

Tengah.JurnalGorga, 1-31.

Irawan, A., \&Luhukay, M. (2012). Representation of Living Values in Batak

Traditional Songs. International Communication and Cultural Conference, 1-29

Panjaitan, O. F. (2010). Kamus Bahasa Batak Toba. Depok.

Porsea, S. (2011, September 29).

Pengertian Umpasa, Umpama dan

Falsafah |

BatakToba .Retrieved from Sian

PorseaTobasa: http://sianporsea.

blogspot.com/2011/09/pengertian-

umpasa-umpama-dan

falsafah.html

Rayking. (2013). Gorga Sopo Godang Pada

Masyarakat Batak Toba Kajian

Semiotik.Thesis.

Ritonga, S. (2012). Orientasi Nilai Budaya

Dan Potensi Konflik Sosial Batak
Toba Muslim dan Kristen di Sumatera Utara.Analisis Volume XII No. 2,

243-268.

Sebeok, T. (2001). Signs: An Introduction to Semiotics. Toronto: University of Toronto Press.

Sianipar, K., Gunardi, G., Widyonugrahanto, \&Rustiyanti, S. (2015). MaknaSeni

UkiranGorgaPadaRumahAdatBatak. Panggung Vol. 25 No. 3, 227-235.

Tobatabo, T. (2013, Juni 21).ApaartiSuhiniAmpangnaOpatdalamad at

50

Batak? Retrieved from Tobatabo: https://www.tobatabo.com/416+apaartisuhini-ampang-na-opat-dalam-adat-batak.htm Wijana, I. D. (2016). Bahasa dan Etnisitas: StudiTentang Nama-namaRumah Makan Padang. Linguistik Indonesia, 195206.

Wikipedia. (2019, August 18). Gorga (art). Retrieved from Wikipedia The Free Encyclopedia: https://en.wikipedia.org/wiki/Gorga_(art) Wong, L. (2008). Data Analysis in Qualitative Research: A Brief Guide to Using

Nvivo. Malays Fam Physician, 14-20. 